\title{
Particle size distribution and chemical composition of total mixed rations for dairy cattle: Water addition and feed sampling effects
}

\author{
C. Arzola-Álvarez, ${ }^{* 1}$ J. A. Bocanegra-Viezca, ${ }^{*}$ M. R. Murphy, $\dagger$ J. Salinas-Chavira, $\ddagger$ A. Corral-Luna, $\dagger$ \\ A. Romanos, ${ }^{*}$ O. Ruíz-Barrera, ${ }^{*}$ and C. Rodríguez-Muela* \\ *Facultad de Zootecnia y Ecología, Universidad Autónoma de Chihuahua, Chihuahua, México 31453 \\ †Department of Animal Sciences, University of Illinois, Urbana 61801 \\ łFacultad de Medicina Veterinaria y Zootecnia, Universidad Autónoma de Tamaulipas, Cd. Victoria, México 87078
}

\section{ABSTRACT}

Four dairy farms were used to determine the effects of water addition to diets and sample collection location on the particle size distribution and chemical composition of total mixed rations (TMR). Samples were collected weekly from the mixing wagon and from 3 locations in the feed bunk (top, middle, and bottom) for 5 mo (April, May, July, August, and October). Samples were partially dried to determine the effect of moisture on particle size distribution. Particle size distribution was measured using the Penn State Particle Size Separator. Crude protein, neutral detergent fiber, and acid detergent fiber contents were also analyzed. Particle fractions 19 to 8,8 to 1.18 , and $<1.18 \mathrm{~mm}$ were judged adequate in all TMR for rumen function and milk yield; however, the percentage of material $>19$ $\mathrm{mm}$ was greater than recommended for TMR, according to the guidelines of Cooperative Extension of Pennsylvania State University. The particle size distribution in April differed from that in October, but intermediate months (May, July, and August) had similar particle size distributions. Samples from the bottom of the feed bunk had the highest percentage of particles retained on the 19-mm sieve. Samples from the top and middle of the feed bunk were similar to that from the mixing wagon. Higher percentages of particles were retained on $>19,19$ to 8 , and 8 to $1.18 \mathrm{~mm}$ sieves for wet than dried samples. The reverse was found for particles passing the 1.18-mm sieve. Mean particle size was higher for wet than dried samples. The crude protein, neutral detergent fiber, and acid detergent fiber contents of TMR varied with month of sampling (18-21, 40-57, and $21-34 \%$, respectively) but were within recommended ranges for high-yielding dairy cows. Analyses of TMR particle size distributions are useful for proper feed bunk management and formulation of diets that maintain rumen function and maximize milk produc-

Received November 26, 2009

Accepted March 25, 2010.

${ }^{1}$ Corresponding author: carzola@uach.mx tion and quality. Water addition may help reduce dust associated with feeding TMR.

Key words: dairy cow, ration, particle size, feed bunk

\section{INTRODUCTION}

Dairy cows with high genetic potential for milk production require high-energy rations to meet nutrient needs. Such diets may cause low intake at the beginning of lactation, and negative associative effects between high energy and finely chopped forages in the diet can be present. Alteration of the physical nature of fiber in forage may also reduce rumination stimuli and saliva flow (Murphy and Zhu, 1996). Dairy cattle diets formulated to supply a minimum of $21 \% \mathrm{NDF}$ from forage sources without consideration of NDF from concentrates reduce DMI, milk yield, and fat in milk and cause health problems such as laminitis, acidosis, ketosis, and displaced abomasum (Beauchemin et al., 1994). The feed industry needs methodology to properly evaluate the effective fiber content of diets that allow maintenance of high milk yield and optimal ruminal health. Among these methodologies is the evaluation of particle size, which is a test to identify the part of fiber in diets that is effective in stimulating rumination and saliva production. In principle, particle size analysis of a diet is similar to analysis of $\mathrm{CP}$ or other nutrient analyses. Particle size distributions and mixing homogeneity can be evaluated together when the aim is to have a homogeneously mixed ration that will have a positive effect on the productive performance of highyielding dairy cows (Grant et al., 1990).

The measurement of the particle size distribution is another tool to maximize DMI and milk yield of dairy cows (Righi et al., 2007). Also, smaller particle size $(<1.18 \mathrm{~mm})$ improved digestion and increased DMI, milk yield, and milk casein and was without effect on milk fat. Zebeli et al. (2008) concluded that increasing the fraction of particles between 8 and $19 \mathrm{~mm}$, and probably the fraction $<8 \mathrm{~mm}$, by decreasing theoretical particle lengths of grass silage does not adversely 
affect rumen conditions and can be beneficial in terms of optimizing concentration and activity of ruminal microbiota in high-yielding dairy cows.

Physically effective NDF (peNDF) measures the physical characteristics of fiber by accounting for particle length and NDF content, which promotes chewing and the flow of salivary buffers to the rumen (Mertens, 1997). The term peNDF is used in diet formulation to provide fiber of adequate particle length to reduce acidosis. Yang and Beauchemin (2007) found that the intake of dietary peNDF is a good indicator of ruminal $\mathrm{pH}$ status of dairy cows and concluded that increasing the proportion of forage in the diet helps prevent ruminal acidosis through increased chewing time, a change in meal patterns, and decreased ruminal acid production. Increasing forage particle size increases ruminal $\mathrm{pH}$, but in low-forage diets increased forage particle size does not completely alleviate subacute acidosis because the fermentability of the diet is high and changes in chewing activity are marginal.

Information is lacking on the effects of water addition during mixing or sample collection location from the feed bunk on particle size distributions of TMR. Our objective was to evaluate the effects of these factors on TMR particle size distributions using the Penn State Particle Separator.

\section{MATERIALS AND METHODS}

\section{Location}

The experiment was conducted in Delicias, Chihuahua, Mexico. The area is located at $28^{\circ} 11^{\prime} \mathrm{N}$ and $105^{\circ} 28^{\prime} \mathrm{W}$ at an altitude of $1,165 \mathrm{~m}$. Annual mean rainfall is $319.8 \mathrm{~mm}$, and the climate is semi-arid (Álvarez, 1980).

\section{Sample Collection}

Feed samples came from TMR fed on 4 similar dairy farms (Holstein cows averaged a total lactation yield through 305 DIM of $9,100 \mathrm{~kg}$ ) that use modern management practices (Table 1). Rations were prepared in feed mixer wagons of 6,000-kg capacity, 3 horizontal augers, and a mixing time averaging $15 \mathrm{~min}$, depending on the time required for delivering the feed through the bunk. During mixing, alfalfa hay was followed by corn silage, cottonseed, concentrate mix, and then water. The amount of water added was different on each farm and was based solely on a management decision of each dairy.

Samples of TMR (about $3 \mathrm{~kg}$ ) were collected at feeding time but before cows began to consume feed. Samples were collected from the mixer wagon and feed

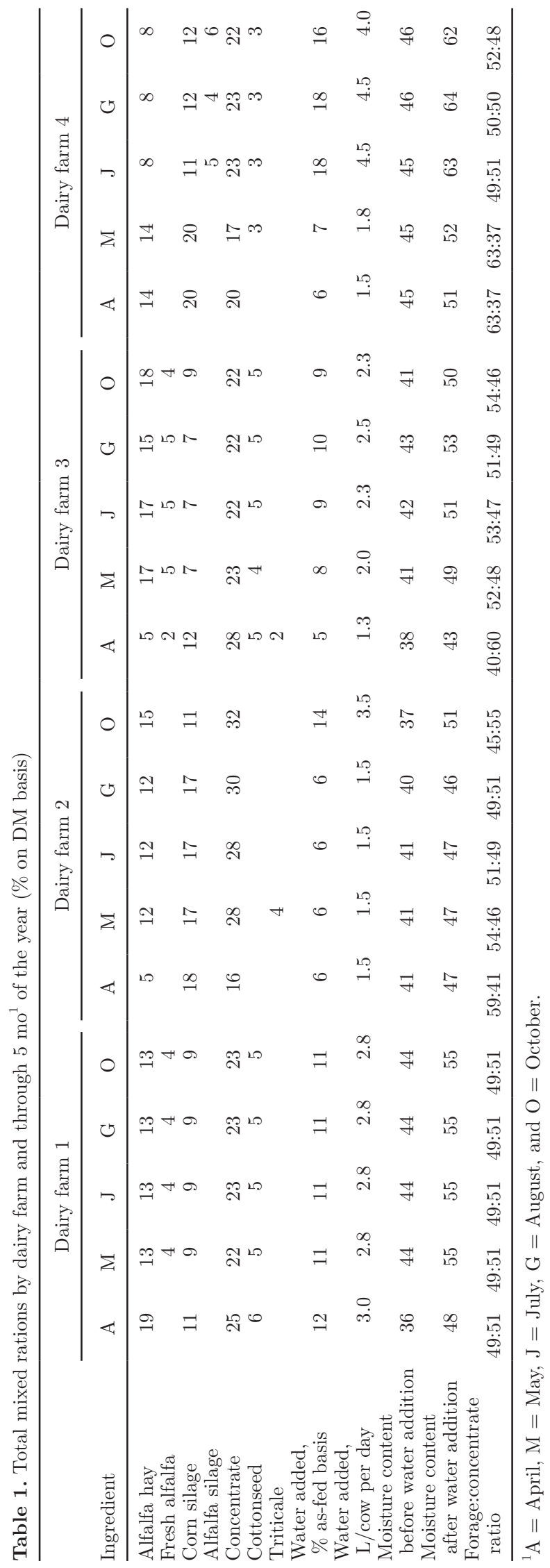

Journal of Dairy Science Vol. 93 No. 9, 2010 
Table 2. Neutral detergent fiber content of $\mathrm{TMR}^{1}$ through 5 mo of the year (\%, DM basis)

\begin{tabular}{lcccccc}
\hline & \multicolumn{5}{c}{ Month } \\
\cline { 2 - 5 } Dairy farm & April & May & July & August & October & SD \\
\hline DF1 & $40.7^{\mathrm{d}}$ & $56.9^{\mathrm{a}}$ & $51.0^{\mathrm{b}}$ & $46.3^{\mathrm{c}}$ & $46.1^{\mathrm{c}}$ & 0.95 \\
DF2 & $46.4^{\mathrm{b}}$ & $43.7^{\mathrm{c}}$ & $42.3^{\mathrm{c}}$ & $42.2^{\mathrm{c}}$ & $55.9^{\mathrm{a}}$ & 0.95 \\
DF3 & $39.5^{\mathrm{c}}$ & $46.8^{\mathrm{b}}$ & $57.1^{\mathrm{a}}$ & $40.3^{\mathrm{c}}$ & $47.5^{\mathrm{b}}$ & 0.95 \\
DF4 & $45.8^{\mathrm{c}}$ & $39.9^{\mathrm{d}}$ & $48.8^{\mathrm{b}}$ & $47.4^{\mathrm{bc}}$ & $52.5^{\mathrm{a}}$ & 0.95 \\
\hline
\end{tabular}

${ }^{\mathrm{a}-\mathrm{d}}$ Means in the same row with different superscripts differ $(P<$ $0.05)$.

${ }^{1}$ Diets included water added during mixing.

bunk (top, middle, and bottom). Samples were obtained weekly from each farm; therefore, 4 samples contributed to monthly means.

\section{Particle Size Determination}

Particle separations were made using the Penn State Particle Separator: the 19-mm plastic sieve, followed by $8-\mathrm{mm}$ and $1.18-\mathrm{mm}$ steel sieves, and then the plastic bottom pan. A sample $(800 \mathrm{~g})$ was placed on the $19-\mathrm{mm}$ sieve. The sieving procedure involved 10 horizontal, $17-\mathrm{cm}$ movements perpendicular to each side of the box, with a total of 40 movements. Screen rotation prevented particle agglomeration. Each sample was analyzed in duplicate. Amounts of sample on each sieve were expressed as a percentage of sample size. It was assumed that samples had a logarithmic-normal distribution with a geometric mean and standard deviation, estimated according to the procedures of ASAE (2001).

To determine the effect of water addition to TMR on particle size distributions, as-fed samples were collected and subjected to particle size separation using the Penn State Particle Separator. Then, to measure the effects of adding water, samples were dried at $55^{\circ} \mathrm{C}$ until constant weight was attained and particle size distributions were determined again.

Table 3. Crude protein content of $\mathrm{TMR}^{1}$ through 5 mo of the year (\%, DM basis)

\begin{tabular}{lllllll}
\hline & \multicolumn{5}{c}{ Month } \\
\cline { 2 - 5 } Dairy farm & April & May & July & August & October & SD \\
\hline DF1 & $17.8^{\mathrm{b}}$ & $18.7^{\mathrm{a}}$ & $18.9^{\mathrm{a}}$ & $17.7^{\mathrm{b}}$ & $18.9^{\mathrm{a}}$ & 0.31 \\
DF2 & $19.1^{\mathrm{ab}}$ & $18.2^{\mathrm{c}}$ & $18.1^{\mathrm{c}}$ & $18.7^{\mathrm{bc}}$ & $19.6^{\mathrm{a}}$ & 0.31 \\
DF3 & $19.6^{\mathrm{bc}}$ & $19.4^{\mathrm{c}}$ & $20.3^{\mathrm{ab}}$ & $19.5^{\mathrm{bc}}$ & $20.9^{\mathrm{a}}$ & 0.31 \\
DF4 & $18.1^{\mathrm{bc}}$ & $17.7^{\mathrm{c}}$ & $18.8^{\mathrm{b}}$ & $17.9^{\mathrm{c}}$ & $20^{\mathrm{a}}$ & 0.31 \\
\hline
\end{tabular}

${ }^{\mathrm{a}-\mathrm{c}}$ Means in the same row with different superscripts differ $(P<$ $0.05)$.

${ }^{1}$ Diets included water added during mixing.
Table 4. Acid detergent fiber content of $\mathrm{TMR}^{1}$ through 5 mo of the year (\%, DM basis)

\begin{tabular}{|c|c|c|c|c|c|c|}
\hline \multirow[b]{2}{*}{ Dairy farm } & \multicolumn{5}{|c|}{ Month } & \multirow[b]{2}{*}{$\mathrm{SD}$} \\
\hline & April & May & July & August & October & \\
\hline DF1 & $28.2^{\mathrm{a}}$ & $26.0^{\mathrm{b}}$ & $25.0^{\mathrm{b}}$ & $26.7^{\mathrm{ab}}$ & $25.5^{\mathrm{b}}$ & 0.67 \\
\hline DF2 & $27.5^{\mathrm{a}}$ & $27.3^{\mathrm{a}}$ & $24.8^{\mathrm{b}}$ & $21.3^{\mathrm{c}}$ & $25.5^{\mathrm{b}}$ & 0.67 \\
\hline DF3 & $26.8^{\mathrm{b}}$ & $29.4^{\mathrm{a}}$ & $23.9^{\mathrm{c}}$ & $23.1^{\mathrm{c}}$ & $29.5^{\mathrm{a}}$ & 0.67 \\
\hline DF4 & $28.3^{\mathrm{b}}$ & $34.1^{\mathrm{a}}$ & $23.3^{\mathrm{c}}$ & $22.8^{\mathrm{c}}$ & $29.2^{\mathrm{b}}$ & 0.67 \\
\hline
\end{tabular}

\section{Chemical Analyses}

Samples were dried at $55^{\circ} \mathrm{C}$ for $24 \mathrm{~h}$ and ground in a Wiley mill (Arthur H. Thomas, Philadelphia, PA) to pass a 1-mm screen. Each sample was analyzed for CP (AOAC, 1990) and NDF and ADF (Goering and Van Soest, 1970).

\section{Statistical Analyses}

Geometric mean particle size, CP, NDF, and ADF were analyzed in a model that included the fixed effects of month, dairy farm (DF), and mixer or feed bunk location and pairwise interactions between these effects. The general linear models procedure of SAS (SAS Institute, 2001) was used and comparisons for significant $(P$ $<0.05)$ variables were made using the PDIFF option. Tabulated percentages of sample recovered on various sieves were also converted to lognormal distributions for graphical presentation.

\section{RESULTS AND DISCUSSION}

\section{Nutrient Composition of TMR}

The NDF contents of TMR are listed in Table 2. Differences in composition within DF but across months are related to changes in TMR formulations over time (Table 1). For example, DF1 fed TMR with more con-

Table 5. Particle size distribution of $\mathrm{TMR}^{1}$ for different dairy farms

\begin{tabular}{|c|c|c|c|c|c|}
\hline \multirow{2}{*}{$\begin{array}{l}\text { Sieve fraction, } \\
\% \text { retained in sieve }\end{array}$} & \multicolumn{4}{|c|}{ Dairy farm } & \multirow[b]{2}{*}{$\mathrm{SD}$} \\
\hline & DF1 & DF2 & DF3 & DF4 & \\
\hline$>19 \mathrm{~mm}$ & $16.0^{\mathrm{b}}$ & $13.9^{\mathrm{c}}$ & $19.4^{\mathrm{a}}$ & $16.0^{\mathrm{b}}$ & 0.42 \\
\hline 19 to $8 \mathrm{~mm}$ & $36.1^{\mathrm{b}}$ & $37.6^{\mathrm{a}}$ & $34.2^{\mathrm{c}}$ & $33.0^{\mathrm{d}}$ & 0.42 \\
\hline 8 to $1.18 \mathrm{~mm}$ & $35.2^{\mathrm{b}}$ & $34.7^{\mathrm{bc}}$ & $33.6^{\mathrm{c}}$ & $38.0^{\mathrm{a}}$ & 0.42 \\
\hline$<1.18 \mathrm{~mm}$ & 12.7 & 13.8 & 12.8 & 13.0 & 0.42 \\
\hline
\end{tabular}


Table 6. Particle size distribution of $\mathrm{TMR}^{1}$ during 5 mo of the year

\begin{tabular}{lllllll}
\hline & \multicolumn{5}{c}{ Month } \\
\cline { 2 - 5 } $\begin{array}{l}\text { Sieve fraction, } \\
\text { \% retained in sieve }\end{array}$ & April & May & July & August & October & SD \\
\hline$>19 \mathrm{~mm}$ & $13.1^{\mathrm{b}}$ & $17.8^{\mathrm{a}}$ & $16.9^{\mathrm{a}}$ & $16.9^{\mathrm{a}}$ & $16.9^{\mathrm{a}}$ & 0.47 \\
19 to $8 \mathrm{~mm}$ & $36.7^{\mathrm{a}}$ & $35.9^{\mathrm{ab}}$ & $36.0^{\mathrm{ab}}$ & $35.1^{\mathrm{b}}$ & $32.5^{\mathrm{c}}$ & 0.47 \\
8 to $1.18 \mathrm{~mm}$ & $34.4^{\mathrm{bc}}$ & $33.7^{\mathrm{c}}$ & $35.7^{\mathrm{b}}$ & $35.2^{\mathrm{b}}$ & $37.9^{\mathrm{a}}$ & 0.47 \\
$<1.18 \mathrm{~mm}$ & $15.8^{\mathrm{a}}$ & $12.6^{\mathrm{b}}$ & $11.4^{\mathrm{c}}$ & $12.8^{\mathrm{b}}$ & $12.7^{\mathrm{b}}$ & 0.47 \\
\hline
\end{tabular}

${ }^{\mathrm{a}-\mathrm{c}}$ Means in the same row with different superscripts differ $(P<$ $0.05)$.

${ }^{1}$ Diets included water added during mixing.

centrate in April and had its lowest content of NDF. In May, fresh alfalfa was incorporated into the TMR and concentrate was reduced, maximizing NDF content.

In general, NDF content of all TMR exceeded minimum recommendations for lactating dairy cows (NRC, 2001). These guidelines also pointed out that rations higher than $44 \%$ NDF may affect intake and digestibility of nutrients. In alfalfa-based diets it has been observed that chewing time is increased from 26 to $34 \%$ with an increase in NDF content (Beauchemin and Buchanan-Smith, 1989). The same effect was observed in barley-based diets (Beauchemin et al., 1994) and in
Table 7. Particle size distribution of $\mathrm{TMR}^{1}$ sampled from various locations

\begin{tabular}{lccccc}
\hline & & \multicolumn{3}{c}{ Feed bunk } & \\
\cline { 3 - 4 } Sieve fraction, \\
\cline { 3 - 5 } \% retained in sieve & Feed mixer & Top & Middle & Bottom & SD \\
\hline$>19 \mathrm{~mm}$ & $15.6^{\mathrm{b}}$ & $15.1^{\mathrm{b}}$ & $15.9^{\mathrm{b}}$ & $18.6^{\mathrm{a}}$ & 0.42 \\
19 to $8 \mathrm{~mm}$ & $35.5^{\mathrm{a}}$ & $35.8^{\mathrm{a}}$ & $35.7^{\mathrm{a}}$ & $33.9^{\mathrm{b}}$ & 0.42 \\
8 to $1.18 \mathrm{~mm}$ & $36.0^{\mathrm{a}}$ & $35.9^{\mathrm{a}}$ & $35.3^{\mathrm{ab}}$ & $34.3^{\mathrm{b}}$ & 0.42 \\
$<1.18 \mathrm{~mm}$ & 12.9 & 13.2 & 13.1 & 13.2 & 0.42 \\
\hline
\end{tabular}

${ }^{\mathrm{a}, \mathrm{b}}$ Means in the same row with different superscripts differ $(P<$ $0.05)$.

${ }^{1}$ Diets included water added during mixing.

corn silage-based diets (Oba and Allen, 2000). These results indicate that NDF stimulates chewing activity; however, concentrations higher than required may affect milk yield. It is possible that relatively high NDF contents of TMR in the present study limited performance.

Crude protein contents of the TMR are shown in Table 3. Although CP differed within DF over time, values were within the recommended range (17-19\%) for high-yielding dairy cows (NRC, 2001). Others have reported similar results (Woodford et al., 1986; West

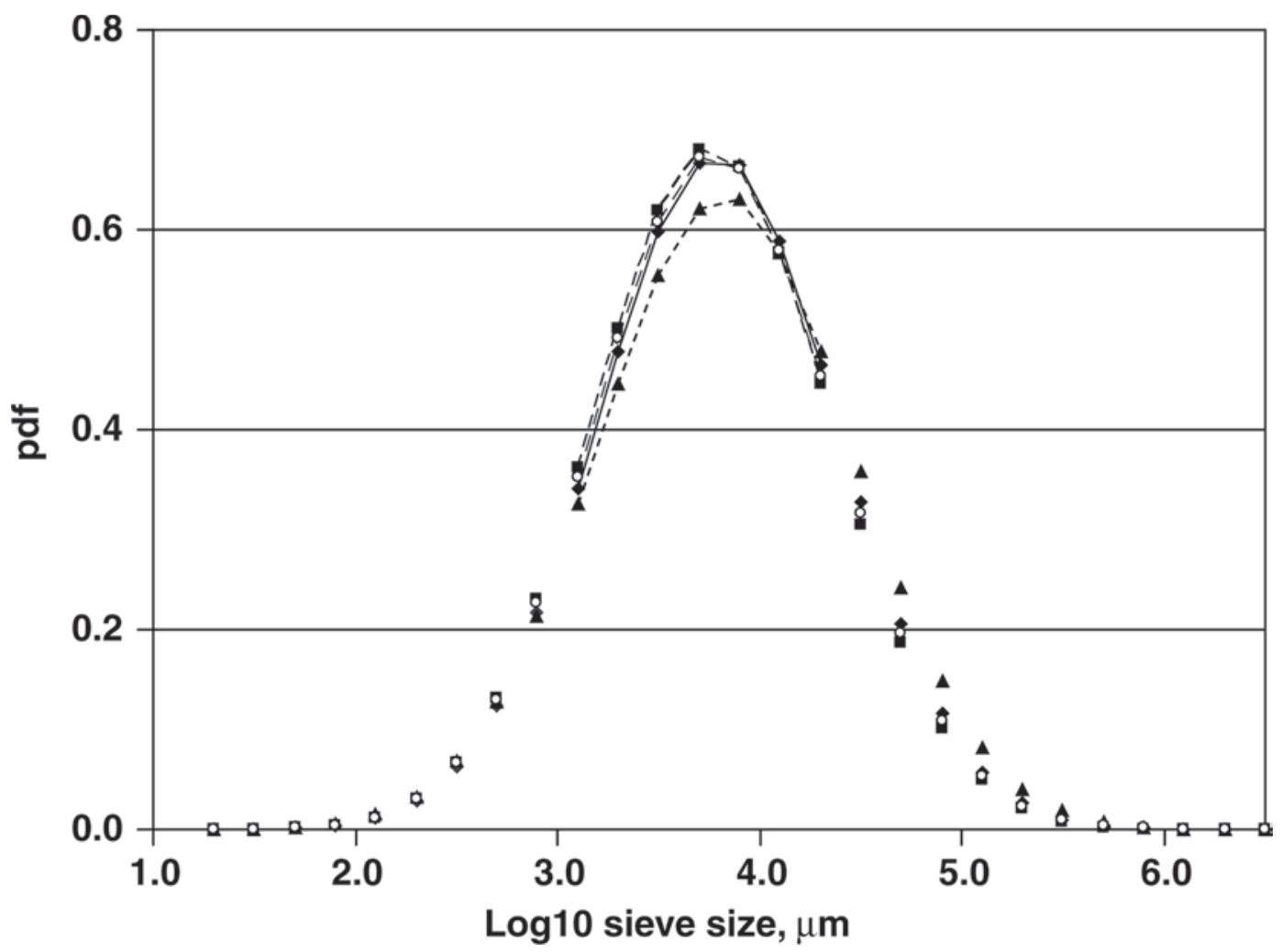

Figure 1. Particle size distributions of TMR from dairy farms $1(\bullet), 2(\mathbf{\square}), 3(\boldsymbol{\Delta})$, and $4(\bigcirc)$. Connected points denote the range of observed data, whereas unconnected points were estimated assuming that the observed data conformed to a lognormal distribution. The probability density function (pdf) describes the distribution of particle size on a logarithmic scale. 
Table 8. Particle size distribution of TMR on as-fed and DM basis

\begin{tabular}{llll}
$\begin{array}{l}\text { Sieve fraction, } \\
\text { \% retained in sieve }\end{array}$ & Wet $^{1}$ & Dry & SD \\
\hline$>19 \mathrm{~mm}$ & $17.4^{\mathrm{a}}$ & $15.2^{\mathrm{b}}$ & 0.3 \\
19 to $8 \mathrm{~mm}$ & $37.3^{\mathrm{a}}$ & $33.2^{\mathrm{b}}$ & 0.3 \\
8 to $1.18 \mathrm{~mm}$ & 35.6 & 35.1 & 0.3 \\
$<1.18 \mathrm{~mm}$ & $9.7^{\mathrm{b}}$ & $16.5^{\mathrm{a}}$ & 0.3 \\
\hline
\end{tabular}

${ }^{\mathrm{a}, \mathrm{b}}$ Means in the same row with different superscripts differ $(P<$ $0.05)$.

${ }^{1}$ Diets included water added during mixing.

et al., 1999; Krause et al., 2002; Reynal and Broderick, 2003).

The ADF contents of TMR are given in Table 4. In general, the values of ADF were above of the minimum recommended for high-yielding dairy cows, but only on DF2 during August did the ADF value approach the minimum recommended (NRC, 2001). Bal et al. (2000) reported ADF contents of $24 \%$ and Woodford et al. (1986) reported ADF contents of 32 to $33 \%$ in corn silage-based diets.

\section{Particle Size Distribution on the Dairy Farms}

Particle size distribution of TMR on the 4 DF is shown in Table 5 and Figure 1. Particle retention on the $19-\mathrm{mm}$ sieve was higher on DF3 and the lowest on DF2 (19.4 and 13.9\%, respectively). These values were higher than the optimum recommended for this sieve, which is between 6 and 10\% (Fisher et al., 1993; Lammers et al., 1996a). For the 8-mm sieve, all dairies differed. The lowest was DF4 and the highest was DF2 (33 and $37.6 \%$ of retained particles, respectively). The increase on the $19-\mathrm{mm}$ sieve reduced retention on the 8 -mm sieve. Values were within the range described by the TMR guides, where the percentage of retention for the $8-\mathrm{mm}$ sieve is recommended to be from 30 to $50 \%$ (Lammers et al., 1996a). The percentage of retained material on the 1.18-mm sieve differed between DF; the highest value was for DF4 and the lowest was for DF3 (38 and $33.6 \%$ of retained particles, respectively). Despite differences between dairies for this sieve, values were within the 30 to $50 \%$ range recommended by TMR guides (Lammers et al., 1996a). All dairy farms

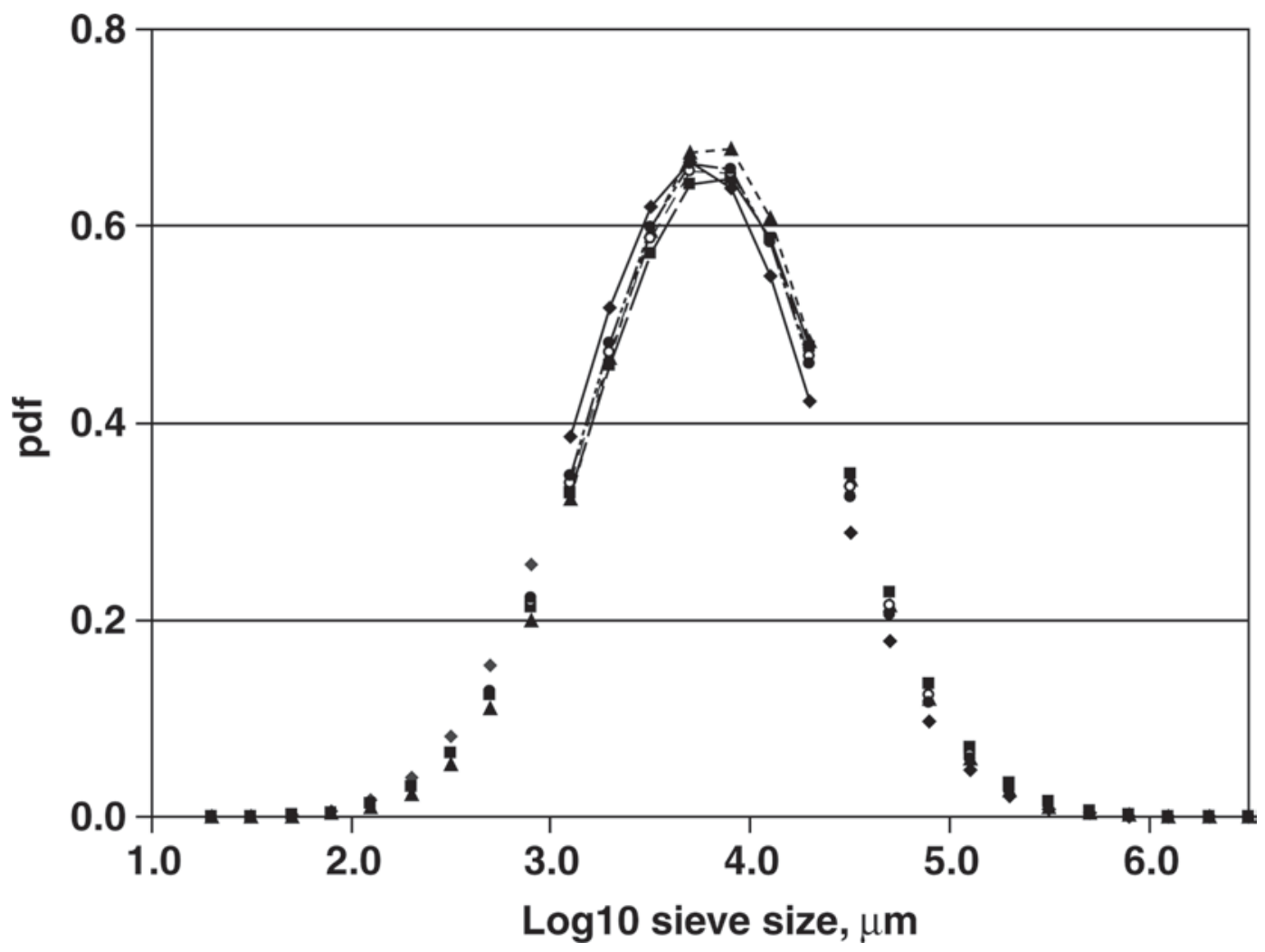

Figure 2. Particle size distributions of TMR in April $(\bullet)$, May $(\boldsymbol{\square})$, July $(\boldsymbol{\Delta})$, August $(\bigcirc)$, and October $(\bullet)$. Connected points denote the range of observed data, whereas unconnected points were estimated assuming that the observed data conformed to a lognormal distribution. The probability density function (pdf) describes the distribution of particle size on a logarithmic scale. 
Table 9. Mean particle size $(\mathrm{mm})$ of $\mathrm{TMR}^{1}$ across 5 mo of the year

\begin{tabular}{lcccccc}
\hline & \multicolumn{5}{c}{ Month } \\
\cline { 2 - 5 } Dairy farm & April & May & July & August & October & SD \\
\hline DF1 & $5.7^{\mathrm{c}}$ & $7.1^{\mathrm{a}}$ & $6.8^{\mathrm{ab}}$ & $7.2^{\mathrm{a}}$ & $6.5^{\mathrm{b}}$ & 0.15 \\
DF2 & $6.7^{\mathrm{a}}$ & $6.2^{\mathrm{b}}$ & $5.6^{\mathrm{c}}$ & $6.3^{\mathrm{b}}$ & $6.3^{\mathrm{b}}$ & 0.15 \\
DF3 & $6.0^{\mathrm{c}}$ & $7.0^{\mathrm{b}}$ & $8.2^{\mathrm{a}}$ & $6.8^{\mathrm{b}}$ & $7.0^{\mathrm{b}}$ & 0.15 \\
DF4 & $5.4^{\mathrm{c}}$ & $7.1^{\mathrm{a}}$ & $7.0^{\mathrm{a}}$ & $6.3^{\mathrm{b}}$ & $6.2^{\mathrm{b}}$ & 0.15 \\
\hline
\end{tabular}

${ }^{\mathrm{a}-\mathrm{c}}$ Means in the same row with different superscripts differ $(P<$ $0.05)$.

${ }^{1}$ Diets included water added during mixing.

had similar percentages of sample on the bottom pan, again within the 0 to $20 \%$ recommended by TMR guides (Lammers et al., 1996a).

Rippel et al. (1997) reported a distribution of particle size on sieves of $>19,19$ to 8 , and 8 to $1.18 \mathrm{~mm}$ of $18.4,42.7$, and $38.7 \%$, respectively, for rations with silages and 22.2, 31.8, and $45.9 \%$, respectively, for rations with hays. Lammers et al. (1996b) found particle size distributions of $6.1,35.5$, and $58.4 \%$, respectively, whereas Heinrichs et al. (1999) reported distributions of $7.0,35.0$, and $58.0 \%$, respectively, in dairy diets. These results differ from the present study (16.3, 35.2 , and $35.4 \%$, respectively) and may be related to forage:concentrate ratio. Forage in the present study ranged from 49 to $62 \%$ of TMR and consisted of alfalfa hay plus corn silage in different proportions.

The results of Mertens (1997) and Yang and Beauchemin (2007) indicate that diets in the present study apparently provided adequate effective fiber for healthy ruminal function. Data of Righi et al. (2007) and Zebeli et al. (2008) suggest that forage:concentrate in the present study could be reduced somewhat, reducing the fraction $>19 \mathrm{~mm}$ and increasing the fraction $<1.18$ $\mathrm{mm}$, thereby improving digestion and milk yield.

Small particles were similarly distributed across farms (Figure 1); however, DF3 had a smaller proportion of medium particles and a higher proportion of large particles. This suggests that DF3 may benefit from additional concentrate in the TMR.

\section{Particle Size Distributions Across Months}

Particle size distributions differed with month of sampling (Table 6; Figure 2). Less material was retained on the 19-mm sieve in April (13.1\%) than in May, July, and August (17.8, 16.9, and 16.9\%, respectively). This could be explained by the shift of usage of alfalfa for corn silage. Results for April agreed with recommendations in the TMR guides.

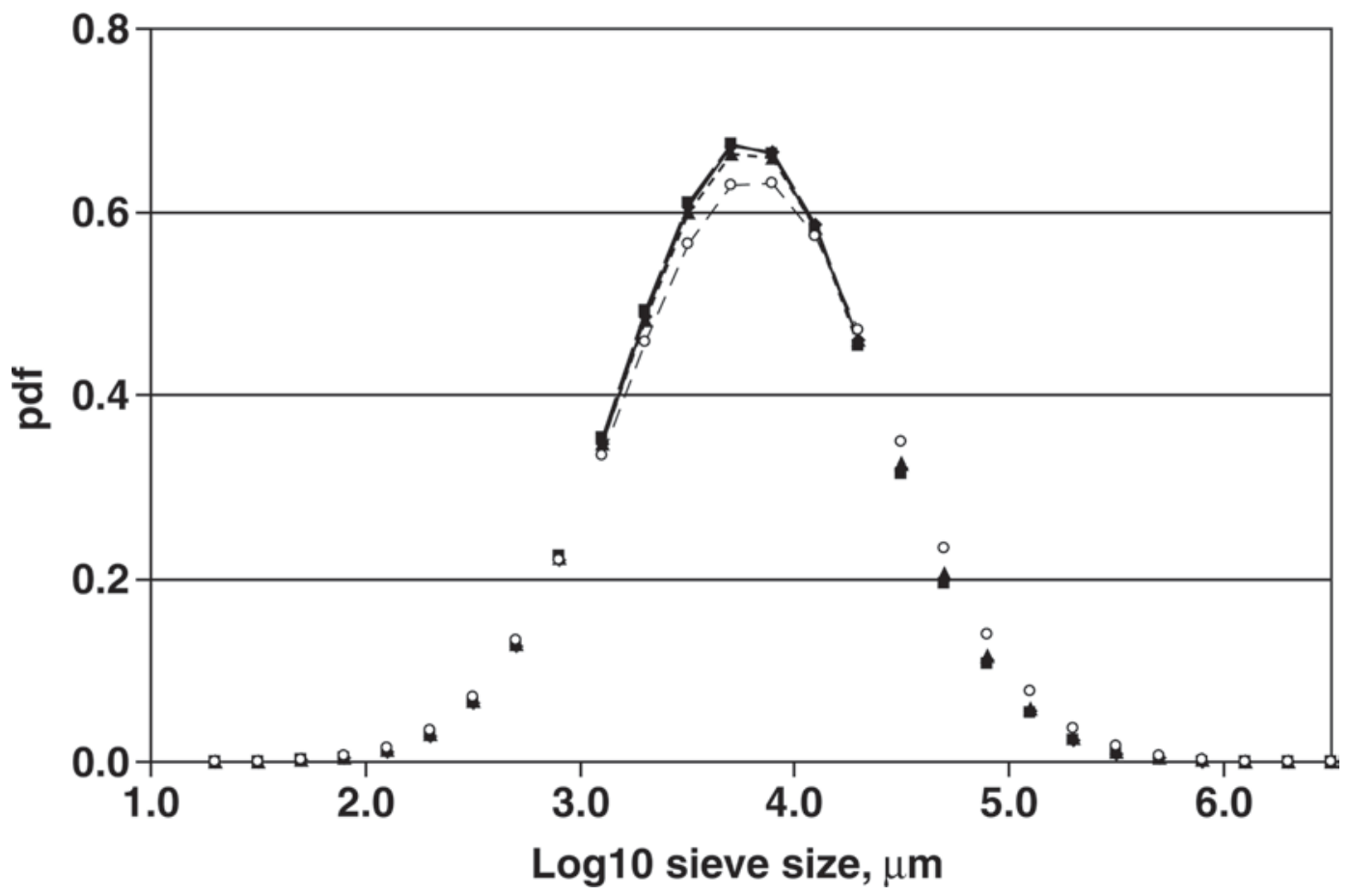

Figure 3. Particle size distributions of TMR sampled from the mixer wagon ( ), the top of the feed bunk ( $\mathbf{\square})$, the middle of the feed bunk $(\boldsymbol{\Lambda})$, or the bottom of the feed bunk $(\bigcirc)$. Connected points denote the range of observed data, whereas unconnected points were estimated assuming that the observed data conformed to a lognormal distribution. The probability density function (pdf) describes the distribution of particle size on a logarithmic scale. 


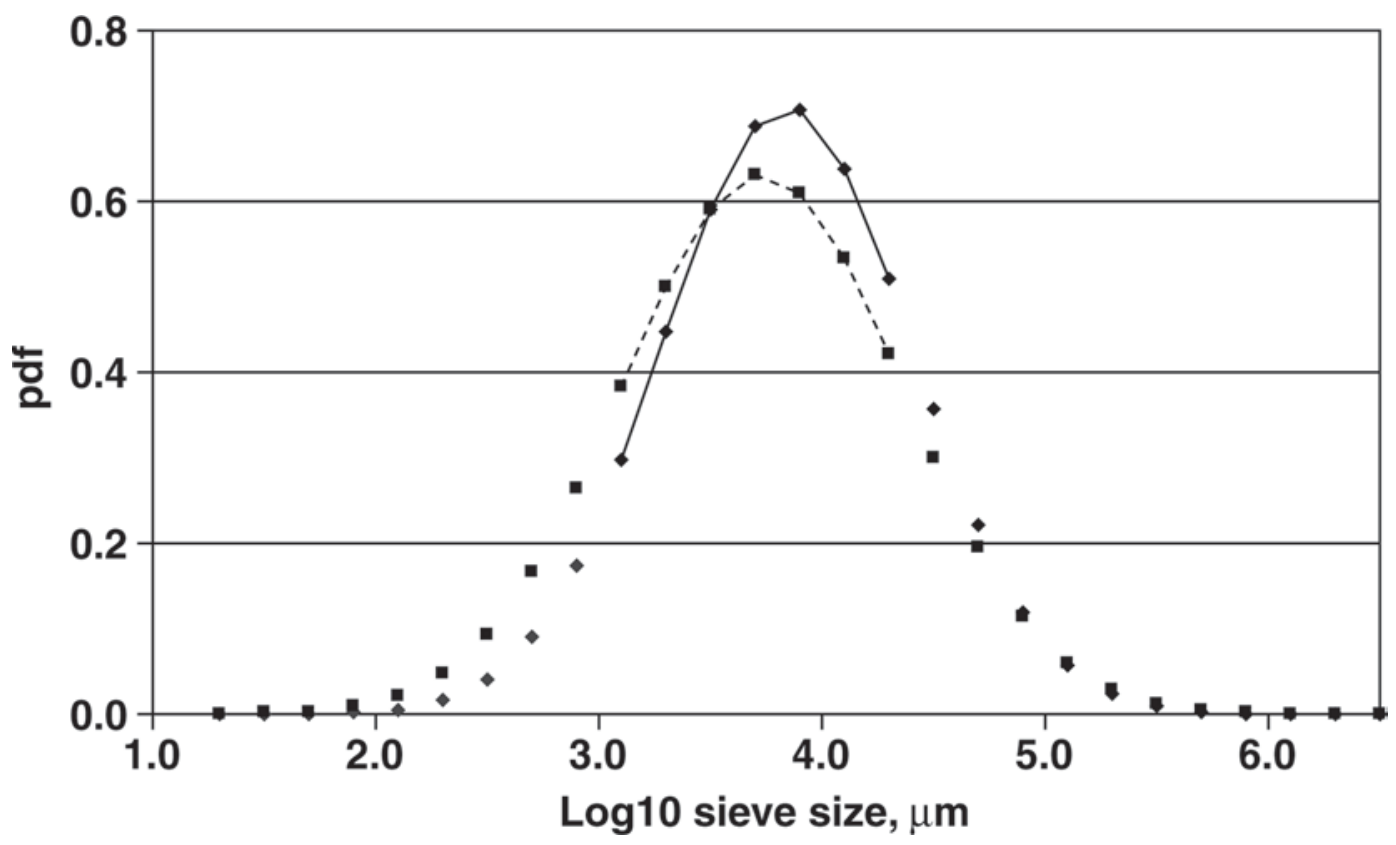

Figure 4. Particle size distributions of TMR on an as-fed ( ) or DM basis ( $\mathbf{\square})$. Connected points denote the range of observed data, whereas unconnected points were estimated assuming that the observed data conformed to a lognormal distribution. The probability density function (pdf) describes the distribution of particle size on a logarithmic scale.

Material between 8 and $1.18 \mathrm{~mm}$ was lowest in October $(32.5 \%)$ and May $(33.7 \%)$ but similar for April, July, and August (34.4, 35.7, and $35.2 \%$, respectively). Particles $<1.18 \mathrm{~mm}$ were highest in April $(15.8 \%)$ and lowest in July (11.4\%); May, August, and October were similar. In general (Figure 2), the lognormal distribution showed that April had higher proportions of small and medium particles and a lower proportion of large particles. Variation between small and medium particle distribution was small in other months, and the distribution of large particles was unchanged. These effects may have resulted from variation in TMR composition over time (Table 1 ).

\section{Particle Size Distributions Within the Feed Bunk}

Table 7 and Figure 3 describe the effect of sampling location with the feed bunk on particle size distribu-

Table 10. Mean particle size $(\mathrm{mm})$ of TMR on as-fed and DM basis

\begin{tabular}{lccc}
\hline Dairy farm & Wet $^{1}$ & Dry & SD \\
\hline DF1 & $7.2^{\mathrm{a}}$ & $6.2^{\mathrm{b}}$ & 0.1 \\
DF2 & $6.8^{\mathrm{a}}$ & $5.6^{\mathrm{b}}$ & 0.1 \\
DF3 & $7.8^{\mathrm{a}}$ & $6.2^{\mathrm{b}}$ & 0.1 \\
DF4 & $6.8^{\mathrm{a}}$ & $6.0^{\mathrm{b}}$ & 0.1 \\
\hline
\end{tabular}

${ }^{\mathrm{a}, \mathrm{b}}$ Means in the same row with different superscripts differ $(P<$ $0.05)$.

${ }^{1}$ Diets included water added during mixing. tions. Samples obtained from the bottom of the feed bunk had more material $>19 \mathrm{~mm}$ and less between 19 and $8 \mathrm{~mm}$ than those taken from other locations. Bottom samples also had less material between 8 and 1.18 $\mathrm{mm}$ than those taken from the top of the feed bunk or the mixer wagon.

Distributions of 19 to 8,8 to 1.18 , and $<1.18 \mathrm{~mm}$ agreed with recommendations for TMR (30-50, 30-50, and $<20 \%$, respectively; Lammers et al., 1996a). More material was $>19.0 \mathrm{~mm}(15-19 \%)$ than recommended (6-10\%; Lammers et al., 1996a). Particle size distributions of samples from within the feed bunk were similar to those taken from the mixer wagon, which indicated that the TMR were properly mixed; however, it is unclear why the fraction of particles $>19.0 \mathrm{~mm}$ was larger in samples from the bottom of the feed bunk (Figure

Table 11. Mean particle size ( $\mathrm{mm})$ of TMR on as-fed and DM basis through 5 mo of the year

\begin{tabular}{llll}
\hline Month & Wet $^{1}$ & Dry & SD \\
\hline April & $6.8^{\mathrm{a}}$ & $5.0^{\mathrm{b}}$ & 0.1 \\
May & $7.6^{\mathrm{a}}$ & $6.1^{\mathrm{b}}$ & 0.1 \\
July & $7.1^{\mathrm{a}}$ & $6.7^{\mathrm{b}}$ & 0.1 \\
August & $7.2^{\mathrm{a}}$ & $6.1^{\mathrm{b}}$ & 0.1 \\
October & $7.1^{\mathrm{a}}$ & $6.0^{\mathrm{b}}$ & 0.1 \\
\hline a,b Means in the same row with different & superscripts & differ $(P<$ \\
$0.05)$. & & \\
${ }^{1}$ Diets included water added during mixing.
\end{tabular}


3). Large particles are expected to rise to the top as samples settle (Rosato et al., 1987).

\section{Particle Size Distributions and Water Addition}

The influence of water addition on particle distributions of TMR is shown in Table 8 and Figure 4. Asfed samples had more material $>19 \mathrm{~mm}$ and between 19 and $8 \mathrm{~mm}$ than did dried samples. Dried samples had more material $<1.18 \mathrm{~mm}$ than did as-fed samples. These results may be attributable to the adherence of smaller particles on bigger particles with water addition, reducing material passing the smallest sieve. This is of practical importance because dust is reduced in TMR by water addition. Other authors have reported reduced sorting and an increment in NDF intake and milk fat percentage when water was added to dry diets (Leonardi et al., 2005).

\section{Mean Particle Size of TMR Across Months}

Mean particle sizes across months are shown in Table 9. For DF1, DF3, and DF4, TMR fed in April had smaller mean particle sizes than those fed in other months; however, those fed in April were larger than other months for DF2. All were large enough to support normal rumination, rumen function, and milk composition in dairy cows fed alfalfa hay (Woodford and Murphy, 1985; Woodford et al., 1986; Shaver et al., 1988).

\section{Mean Particle Size and Water Addition}

The effect of water addition on the geometrical mean of particle size of TMR in dairy farms is shown in Table 10. All dairy farms had higher mean particle sizes in as-fed than in dried TMR samples. The same was found for TMR across months (Table 11). Although mean particle sizes were higher in wet than in dry rations, all cases were acceptable $(>5 \mathrm{~mm})$ to maintain ruminal $\mathrm{pH}$, ruminal activity, and fat milk (Woodford and Murphy, 1985; Woodford et al., 1986; Shaver et al., 1988).

\section{CONCLUSIONS}

Differences in particle size distributions throughout the year were related to changes in TMR composition. The TMR were properly mixed, but a higher percentage of particles $>19 \mathrm{~mm}$ were present in samples from the bottom of the feed bunk than from other locations. Water addition during mixing reduced the percentage of smaller particles $(<1.18 \mathrm{~mm})$ in rations. Particle size and nutrient composition of TMR indicated that all were appropriate for normal rumen function and milk production.

\section{REFERENCES}

Álvarez, G. A. 1980. Boletín meteorológico del estado de Chihuahua. Dirección de Geografía y Meteorología. SARH. Gobierno del Estado.UGRCh Chihuahua, México.

ASAE. 2001. S424. Method of determining and expressing particle size of chopped forage materials by sieving. In Standards Am. Soc. Agric. Eng. ASAE, St. Joseph, MI.

Association of Official Analytical Chemists. 1990. Official Methods of Analysis. 15th ed. AOAC, Arlington, VA.

Bal, M. A., R. D. Shaver, A. G. Jirovec, K. J. Shinners, and J. G. Coors. 2000. Crop processing and chop length of corn silage: Effects on intake, digestion, and milk production by dairy cows. J. Dairy Sci. 83:1264-1273.

Beauchemin, K. A., and J. G. Buchanan-Smith. 1989. Effects of dietary neutral detergent fiber concentration and supplementary long hay on chewing activities and milk production of dairy cows. J. Dairy Sci. $72: 2288-2300$.

Beauchemin, K. A., B. I. Farr, L. M. Rode, and G. B. Schaalje. 1994. Effects of alfalfa silage chop length and supplementary long hay on chewing and milk production of dairy cows. J. Dairy Sci. 77:1326-1339.

Fisher, J. M., J. G. Buchanan-Smith, C. Campbell, D. G. Grieve, and O. B. Allen. 1993. Effects of forage particle size and long hay for cows fed total mixed rations based on alfalfa and corn. J. Dairy Sci. $77: 217-229$.

Goering, H. K., and P. J. Van Soest. 1970. Forage fiber analyses (apparatus, reagents, procedures, and some applications). Agric. Handbook No. 379. ARS-USDA, Washington, DC.

Grant, R. J., V. F. Colenbrander, and D. R. Mertens. 1990. Milk fat depression in dairy cows: Role of particle size of alfalfa hay. J. Dairy Sci. 73:1823-1833.

Heinrichs, A. J., D. R. Buckmaster, and B. P. Lammers. 1999. Processing, mixing, and particle size reduction of forages for dairy cattle. J. Anim. Sci. 77:180-186.

Krause, K. M., D. K. Combs, and K. A. Beauchemin. 2002. Effects of forage particle size and grain fermentability on performance and ruminal $\mathrm{pH}$ in midlactation cows. I. Milk production and diet digestibility. J. Dairy Sci. 85:1936-1946.

Lammers, B. P., D. R. Buckmaster, and A. J. Heinrichs. 1996a. A simple method for the analysis of particle sizes of forage and total mixed rations. J. Dairy Sci. 79:922-928.

Lammers, B. P., A. J. Heinrichs, R. T. Ward, and D. R. Buckmaster. 1996b. Forage and TMR particle size distribution used by farmers in the northeast. J. Dairy Sci. 79(Suppl. 1):153.

Leonardi, C., F. Giannico, and L. E. Armentano. 2005. Effect of water addition on selective consumption (sorting) of dry diets by dairy cattle. J. Dairy Sci. 88:1043-1049.

Mertens, D. R. 1997. Creating a system for meeting the fiber requirements of dairy cows. J. Dairy Sci. 80:1463-1481.

Murphy, M. R., and J. S. Zhu. 1996. A comparison of methods to analyze particle size as applied to alfalfa haylage, corn silage, and concentrate. J. Dairy Sci. 80:2932-2938.

National Research Council. 2001. Nutrient Requirements of Dairy Cattle. 7th rev. ed. National Academy Press, Washington, DC.

Oba, M., and M. S. Allen. 2000. Effects of brown midrib 3 mutation in corn silage on productivity of dairy cows fed two concentrations of dietary neutral detergent fiber: 2. Chewing activities. J. Dairy Sci. 83:1342-1349.

Reynal, S. M., and G. A. Broderick. 2003. Effects of feeding dairy cows protein supplements of varying ruminal degradability. J. Dairy Sci. 86:835-843.

Righi, F., A. Quarantelli, L. Tonelli, M. Renzi, and B. Gandolfi. 2007. Use of the Penn State Particle Separator for the evaluation of total mixed rations typical of Parmigiano Reggiano cheese production area. Ital. J. Anim. Sci. 6(Suppl. 1):347-349.

Rippel, C. M., E. R. Jordan, and S. R. Stokes. 1997. Evaluation of particle size distribution and ration uniformity in total mixed rations fed in Northcentral Texas. Prof. Anim. Sci. 14:44-50.

Rosato, A., K. J. Strandburg, F. Prinz, and R. H. Swendsen. 1987. Why the Brazil nuts are on top: Size segregation of particulate matter by shaking. Phys. Rev. Lett. 58:1038-1040. 
SAS Institute. 2001. User's Guide: Statistics. Version 8. SAS Inst. Inc., Cary, NC.

Shaver, R. D., A. J. Nyted, L. D. Satter, and N. A. Jorgensen. 1988. Influence of feed intake, forage physical form, and fiber content on particle size of masticated forage, ruminal digesta, and feces of dairy cows. J. Dairy Sci. 71:1566-1572.

West, J. W., G. M. Hill, J. M. Fernández, P. Mandebvu, and B. G. Mullinix. 1999. Effects of dietary fiber on intake, milk yield, and digestion by lactating dairy cows during cool or hot, humid weather. J. Dairy Sci. 82:2455-2465.

Woodford, J. A., N. A. Jorgensen, and G. P. Barrington. 1986. Impact of dietary fiber and physical form on performance of lactating cows. J. Dairy Sci. 69:1035-1047.
Woodford, S. T., and M. R. Murphy. 1985. Dietary alteration of particle breakdown and passage from the rumen in lactating dairy cattle. J. Dairy Sci. 68:687-698.

Yang, W. Z., and K. A. Beauchemin. 2007. Altering physically effective fiber intake through forage proportion and particle length: Chewing and ruminal pH. J. Dairy Sci. 90:2826-2838.

Zebeli, Q., M. Tafaj, B. Junck, D. Mansmann, H. Steingass, and W. Drochner. 2008. Evaluation of the effects of dietary particle fractions on fermentation profile and concentration of microbiota in the rumen of dairy cows fed grass silage-based diets. Arch. Anim. Nutr. 62:230-240. 